\title{
Kebar Grass Extract (Biophitum Petersianum) Increases Diameter Of The Seminiferous Tubules Of Diabetic Mice
}

\author{
Faraida Arvilla', Reny I'tishom ${ }^{2}$, Bambang Purwanto ${ }^{3}$ \\ ${ }^{1}$ Reproductive Health Science Faculty of Medicine, Airlangga University. \\ ${ }^{2}$ Department of Medical Biology, Faculty of Medicine, Airlangga University. \\ ${ }^{3}$ Department of Medical Physiology, Faculty of Medicine, Airlangga University. \\ Email : faraida.arvilla19@gmail.com
}

Receive : May $9^{\text {th }}$ 2020. Revised : Mart 25 ${ }^{\text {th }}$ 2021. Published: June $10^{\text {th }} 2021$

DOI : https://doi.org/10.22219/sm.Vol17.SMUMM1.12150

\begin{abstract}
Diabetes is a metabolic disease that can affect the male reproductive system. The condition of hyperglycemia will increase the production of ROS, causing oxidative stress. Oxidative stress causes microangiopathy, triggers cell apoptosis, interferes with spermatogenesis, thereby affecting the diameter of the seminiferous tubules. Kebar grass contains of flavonoid and vitamin $\mathrm{E}$ which can be used to reduce ROS reactions and inhibit oxidative stress. This research was to prove that kebar grass extract can increase diameter of the seminiferous tubules of diabetic mice. This research is a true experimental design with post test only control group design. Total of 30 samples were divided into 5 groups: negative control group (K-) was given CMC$\mathrm{Na}$, positive control group $(\mathrm{K}+)$ was given metformin $2 \mathrm{mg} / \mathrm{kg}$, groups $\mathrm{P} 1, \mathrm{P} 2$ and $\mathrm{P} 3$ received $2 \mathrm{mg} / \mathrm{kg}$ metformin and kebar grass extract with different dosages $(67.5 \mathrm{mg} / \mathrm{kg}, 135 \mathrm{mg} / \mathrm{kg}$ and $270 \mathrm{mg} / \mathrm{kg}$ ). The treatment lasted for 35 days. On the 36th day the mice were sacrificed and the testes were taken, then histological observations were made with HE staining to measure the diameter of tubules. The result showed that there was a significant difference in the diameter of seminiferous tubules with $\mathrm{p}$ value $=0,000$. Kebar grass extract can increase the diameter of seminiferous tubules of diabetic mice.
\end{abstract}

Keywords : diabetes mellitus, diameter of the seminiferous tubules, kebar grass.

Copyright (C) 2021, Arvilla F. et al This is an open access article under the CC-BY-SA license

\section{INTRODUCTION}

Diabetes mellitus is a global health problem because it affects more than 400 million people worldwide and is expected to increase to more than 600 million by 2045 (International Diabetes Federation, 2017). Indonesia get sixth ranks in the world for the highest prevalence of diabetes mellitus after China, India, the United States, Brazil and Mexico with 10.3 million diabetics (International Diabetes Federation, 2017).

Diabetes mellitus is a chronic metabolic disorder due to the pancreas not being able to produce enough insulin or the body cannot use insulin that has been produced effectively (Kementrian kesehatan, 2014). This disease is characterized byincreased glucose levels that exceed 
normal (hyperglycemia) associated with long-term damage, dysfunction and failure of several organs in the patient's body (Singh et al., 2012). Clinical and experimental data indicate that diabetes adversely affects reproductive function especially in men which can cause a decrease in fertility rates (Maresch et al., 2018). Diabetes mellitus describes a group of metabolic disor-derscharacterised by high blood glucose levels (Cho et al., 2018). Conditions of high glucose levels in the blood can cause excessive ROS formation in the body resulting in oxidative stress. One of the primary markers of excessive ROS formation is an increase in malondialdehyde (MDA). Increased levels of MDA in plasma, liver, and tissue have been reported in diabetic patients (Tiwari et al., 2013). Oxidative stress that occurs in the testes will result in damage to the mitochondrial membrane and cause loss of potential function of the mitochondrial membrane which will lead to cell death or apoptosis. Oxidative stress also causes damage to blood vessel endothelium and causes microangiopathy, which interferes with the supply of nutrients through the blood vessels to the spermatozoa-forming tissues. That will interferes the process of spermatogenesis that occurs in the seminiferous tubules (La Vignera et al., 2015).

Oxidative stress cannot be overcome by endogenous antioxidants, so they requires exogenous antioxidants. Therefore, we need medicines that contain of exogenous antioxidants that work on free radicals and prevent the effects of damage to the body. Flavonoids and vitamin $\mathrm{E}$ are one of the exogenous antioxidant groups,as radical-scavenging antioxidants that capture free radicals before free radicals attack lipids and capture peroxyl lipid radicals (Yuslianti, 2018).One source of exogenous antioxidants in Indonesia is the kebar grass (Biophytum petersianum Klotzsch). Kebar grass is a medicinal plant that grows in Indonesia, especially in West Papua, has been used for generations by local people as traditional medicine in improving reproductive performance (Unitly \& Inara, 2011). Kebar grass contains of antioxidant compounds namely flavonoids and vitamin $\mathrm{E}$ which can stabilize free radicals by completing the lack of electrons and inhibiting oxidative stress. The entry of compounds contained in the kebar grass through the blood will reach all cells and tissues of the body including the reproductive organs, namely the testes in which there are seminiferous tubules where spermatogenesis occurs. Active antioxidants contained in kebar grass can reduce oxidative damage to cells and prevent the death of spermatogenic cells in the seminiferous tubules (Lefaan et al., 2014).

Various studies on the effects of kebar grass (Biophytum petersianum Klotzsch) on reproduction in animals have been carried out. Kebar grass infusion can increase spermatogenesis activity in male mice (Lefaan et al., 2014). In addition, kebar grass extract is effective for maintaining the quality of the spermatozoa of mice from damage due to exposure to 2,3,7,8-tetrachlorodibenzo-p-dioxin (Kurnijasanti \& Suprayogi, 2020).

Given the previous research that has been carried out, kebar grass has been shown to have a good effect on male fertility. In this study, the researchers intend to conduct research on the effects of Kebar grass (Biophytum petersianum Klotzsch) given to diabetes mellitus model mice. 
The aim of this study is to prove the potential for administration of kebar grass extract (Biophytum petersianum Klotzsch) in increasing the diameter of the seminiferous tubules of diabetic mice.

\section{METHODS}

This research wastrue experimental design research with post test only control group design. The research was conducted at the Faculty of Medicine, Airlangga University between November 2019 to January 2020. The sample in this study was male mice from Balb/C strains aged 6-8 weeks, body weight 20-30gram.

The making ofkebar grass extract is macerated with $70 \%$ ethanol solvent. Mice were made diabetic by intraperitonially inducing streptozotocin $40 \mathrm{mg} / \mathrm{kg}$ BW for 5 consecutive days. Successful induction of streptozotocin is characterized by blood sugar levels of mice> $200 \mathrm{mg} / \mathrm{dL}$.

The samples of 30 diabetic mice were divided into 5 groups: negative control group (K-), positive control group $(\mathrm{K}+)$ were given metformin $2 \mathrm{mg} / \mathrm{kg}$, groups P1, P2 and P3 received metformin $2 \mathrm{mg} / \mathrm{kg}$ and kebar grass extract with different doses $(67.5 \mathrm{mg} / \mathrm{kg}, 135 \mathrm{mg} / \mathrm{kg}$ and $270 \mathrm{mg} / \mathrm{kg}$ ). After 35 days of treatment, the mice were sacrificed and dissected for their testicular organs, then microscopic preparations were made using the paraffin method and Hematoxylin Eosin staining. The diameter of the seminiferous tubules is measured under a light microscope at 400x magnification in 10 visual fields. Statistical analysis was performed with the Anova test.

\section{RESULTS AND DISCUSSION}

The aim of this study was to prove that administration of kebar grass extract can increase the diameter of the seminiferous tubules in diabetic mice.

Table. 1 Mean and standart deviation, shapiro-wilk test, levenne test, and anova testdiameter of the seminiferous tubules of diabetic mice.

\begin{tabular}{ccccc}
\hline Groups & Mean \pm SD & Shapiro-wilk test & Levenne test & Anova \\
\cline { 3 - 5 } & & & p value & \\
\hline negative control group & $195.82 \pm 8.74$ & 0.993 & 0.056 & $0.000^{*}$ \\
positive control group & $230.17 \pm 26.42$ & 0.182 & & \\
Kebar grass $67,5 \mathrm{mg} / \mathrm{kg} \mathrm{BB}$ & $230.55 \pm 14.12$ & 0.789 & & \\
Kebar grass $135 \mathrm{mg} / \mathrm{kg} \mathrm{BB}$ & $239.61 \pm 5.73$ & 0.522 & & \\
Kebar grass $270 \mathrm{mg} / \mathrm{kg} \mathrm{BB}$ & $244.86 \pm 18.23$ & 0.436 & & \\
\hline
\end{tabular}

${ }^{*} \mathrm{p}>0,05=$ significant difference.

Table 1showed the highest average diameter of the seminiferous tubules of diabetic mice was at dose of $270 \mathrm{mg} / \mathrm{kg}$ (244.86), while the lowest was in the negative control group (195.82). 
Anova test results of seminiferous tubule diameter is $\mathrm{p}=0,000(\mathrm{p}<0.05)$ which means there is a significant difference in the seminiferous tubule diameter of all groups of mice. These results prove that the induction of streptozotocin causes hyperglycemia which causes oxidative stress, interfering with the formation of spermatozoa so that it can reduce the diameter of the seminiferous tubules of diabetic mice.

Research by $\mathrm{Xu}$ ( $\mathrm{Xu}$ et al., 2014) states that rats injected with streptozotocin show an increased apoptosis index of Sertoli cells and decreased number of leydig cells (Kermani et al., 2019). The same thing was also expressed by Kong et al (Kong et al., 2018), that diabetes mellitus can stop the growth and development (atrophy) of Leydig cells and Sertoli cells. Sertoli cells are somatic cells in the seminiferous tubular epithelium that provide support for the development and maturation of germ cells in the seminiferous tubules, so that the apoptosis of Sertoli cells will affect germ cells in the seminiferous tubules. Research by Bozkurt et al (Bozkurt et al., 2018) states that diabetes mellitus rats with streptozotocin induction result in oxidative stress which affects the spermatogenesis process. The same thing was also expressed by Adelati et al (Adelati et al., 2016) that the hyperglycemia condition in diabetes can interfere with the stage of spermatogenesis, causing degeneration of spermatogenic cells in the seminiferous tubules (Öztaş et al., 2019) thereby affecting the diameter of the seminiferous tubules in mice.

The hyperglycemia state causes the buildup of Advanced Glycation End Products (AGEs) and increases the formation of Reactive Oxygen Species (ROS) (Rhee \& Kim, 2018). The formation of reactive oxygen compounds can increase the modification of lipids, DNA, and proteins in various tissues. Molecular modification in these tissues results in an imbalance between protective antioxidants (antioxidant defenses) and increased ROS production. ROS production is actually a physiological process of the body but if there is an imbalance between production and elimination by antioxidants in the body, accumulation of ROS in tissues can cause oxidative stress. Oxidative stress that occurs in the testes will result in damage to the mitochondrial membrane and cause loss of potential function of the mitochondrial membrane which will lead to cell death or apoptosis (La Vignera et al., 2015), causes disruption of spermatogenesis and decreased sperm quality (Aitken et al., 2014).

Diabetes mellitus causes an increase in ROS that damage the mitochondrial membrane. This causes a loss of potential function of the mitochondrial membrane and will induce apoptosis of spermatozoa. This is the same as the research of Anindita and Sutyarso (Anindita \& Sutyarso, 2012) which states that the diameter of the seminiferous tubules is influenced by the spermatozoa production.

Diabetes mellitus ratsget damage to the reproductive system by showing testicular dysfunctions (Fatani et al., 2015), reduction in tubulardiameter and volume (Abbasi et al., 2013), irregular spermatogenic cells, inhibited spermatogenesis and vacuolization in spermatogenic cells (Oladipo et al., 2018). 

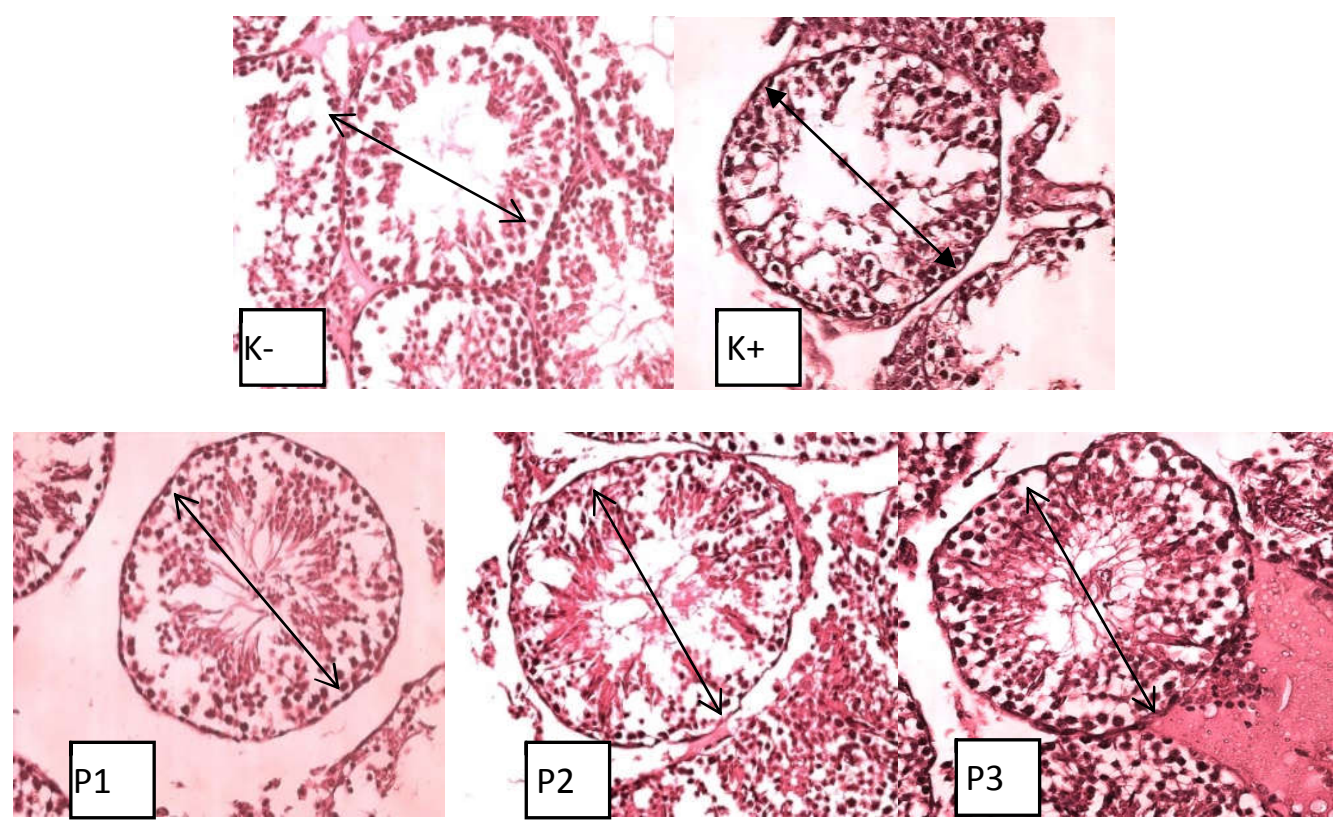

Figure 1. Histological picture of seminiferous tubules using a light microscope with 400x magnification with HE staining in the negative control group $\mathrm{K}-(\mathrm{CMC} \mathrm{Na} 1 \%)$, positive control group $(\mathrm{K}+$ ) (metformin $2 \mathrm{mg} / \mathrm{kg}$ ), P1 group (metformin $2 \mathrm{mg} / \mathrm{kg}+$ kebar grass extract dose $67.5 \mathrm{mg} / \mathrm{kg}$ ), P2 group (metformin $2 \mathrm{mg} / \mathrm{kg}+$ kebar grass extract dose $135 \mathrm{mg} / \mathrm{kg}$ ), and group P3 (metformin $2 \mathrm{mg} / \mathrm{kg}+$ kebar grass extract dose $270 \mathrm{mg} / \mathrm{kg}$ ).

Figure 1 can be seen that the group that received the kebar grass extract (Biophytum petersianum) showed a significant difference in the diameter of the seminiferous tubules compared to the negative control mice group. This is caused by the kebar grass has several active ingredients that act as antioxidants, namely flavonoids and vitamin E (Sembiring \& Darwati, 2016). These antioxidants can eliminate free radicals and reduce oxidative stress, so the amount of ROS and antioxidants is in a balanced state so as to reduce the negative effects of oxidants (Sayuti \& Rina, 2015). Antioxidant enzymes will reduce oxidative damage to cells and can inhibit apoptosis in germ cells of testicular diabetic mice (Mallick et al., 2010). Unitly (Unitly \& Inara, 2011) in his research explained that the kebar grass (Biophytum petersianum) can increase the activity of cells that produce FSH and LH in the pituitary.This increase will trigger an increase in the production of the hormones testosterone and ABP (Androgen Binding Protein) which are used in the spermatogenesis process.

Flavonoid has a significant effect on increasing spermatogenesis activity in mice (Lefaan et al., 2014), and vitamin $\mathrm{E}$ plays a role in the formation of the hormone testosterone so that it can increase the process of spermatogenesis (Sembiring \& Darwati, 2016). The optimal spermatogenesis process will produce good spermatozoa that will increase the diameter of the seminiferous tubules. This is same with the research of Yue et al (Yue et al., 2010), which states that vitamin $\mathrm{E}$ can increase the diameter of the seminiferous tubules. Vitamin $\mathrm{E}$ as antioxidant plays a role as a primary protector against oxidative stress and prevents the production of lipid peroxide by 
free radicals. It shows that the content of kebar grass (Biophytum petersianum Klotzsch) can increase the diameter of the seminiferous tubules of diabetic mice.

\section{CONCLUSION}

Kebar grass extract (Biophytum petersianum Klotzsch) can increase the diameter of the seminiferous tubules in diabetic mice (Musmusculus). Similar research needs to be done in the future to see testosterone levels in diabetic mice.

\section{REFERENCES}

Abbasi, Z., Tabatabaei, S. R. F., Mazaheri, Y., Barati, F., \& Morovvati, H. (2013). Effects of Sesame Oil on the Reproductive Parameters of Diabetes Mellitus-Induced Male Rats. The World Journal of Men's Health, 31(2), 141. https://doi.org/10.5534/wjmh.2013.31.2.141

Adelati, S., Juniarto, A., \& Miranti, I. (2016). Histopatologi Spermatogenesis Testis Tikus Wistar Diabetes Melitus. Jurnal Kedokteran Diponegoro, 5(4), 1760-1769.

Aitken, R. J., Smith, T. B., Jobling, M. S., Baker, M. A., \& De Iuliis, G. N. (2014). Oxidative stress and male reproductive health. Asian Journal of Andrology, 16(1), 31-38. https://doi.org/10.4103/1008-682X.122203

Anindita, K., \& Sutyarso. (2012). Pengaruh Pemberian Vitamin C terhadap Berat Testis, Jumlah sel Leydig, dan Diameter Tubulus Seminiferus Mencit (Mus musculus L) Jantan Dwasa yang diinduksi Monosodium Glutamat. Medical Journal of Lampung University, 1(1), 36-48.

Bozkurt, A., Karabakan, M., Aydin, M., Gumustas, S., Onk, D., Gursul, C., \& Erol, H. (2018). Effects of melatonin treatment on the spermatogenesis and serum inflammatory cytokine levels in diabetic rats. Annals of Medical Research, 25(4), 1. https://doi.org/10.5455/annalsmedres.2018.09.192

Cho, N. H., Shaw, J. E., Karuranga, S., Huang, Y., da Rocha Fernandes, J. D., Ohlrogge, A. W., \& Malanda, B. (2018). IDF Diabetes Atlas: Global estimates of diabetes prevalence for 2017 and projections for 2045. Diabetes Research and Clinical Practice, 138, 271-281. https://doi.org/10.1016/j.diabres.2018.02.023

Fatani, A. J., Al-Rejaie, S. S., Abuohashish, H. M., Al-Assaf, A., Parmar, M. Y., \& Ahmed, M. M. (2015). Lutein Dietary Supplementation Attenuates Streptozotocin-induced testicular damage and oxidative stress in diabetic rats. BMC Complementary and Alternative Medicine, 15(1), 1-10. https://doi.org/10.1186/s12906-015-0693-5

International Diabetes Federation. (2017). IDF diabetes atlas 8th edition. International Diabetes Federation.

Kementrian kesehatan, R. I. (2014). Situasi dan analisis diabetes. Jakarta: Pusat Data dan Informasi Kemenkes RI.

Kermani, J., Goodarzi, N., \& Bakhtiari, M. (2019). An Experimental Study to Evaluate the 
Protective Effects of Solanum lycopersicum Seed Essential Oil on Diabetes-Induced Testicular Injuries. Medicina, 55(8), 499. https://doi.org/10.3390/medicina55080499

Kong, Z.-L., Johnson, A., Ko, F.-C., He, J.-L., \& Cheng, S.-C. (2018). Effect of Cistanche Tubulosa Extracts on Male Reproductive Function in Streptozotocin-Nicotinamide-Induced Diabetic Rats. Nutrients, 10(10), 1562. https://doi.org/10.3390/nu10101562

Kurnijasanti, R., \& Suprayogi, T. W. (2020). INTERNATIONAL JOURNAL OF RESEARCH IN musculus ) sperm quality exposed to dioxin. 11(3), 4977-4981.

La Vignera, S., Condorelli, R. A., Di Mauro, M., Lo Presti, D., Mongioì, L. M., Russo, G., \& Calogero, A. E. (2015). Reproductive function in male patients with type 1 diabetes mellitus. Andrology, 3(6), 1082-1087. https://doi.org/10.1111/andr.12097

Lefaan, P. N., Bioteknologi, F., Kristen, U., \& Wacana, D. (2014). Pengarub Infusa Rumput Kebar ( Biophytum petersianum) terbadap Spermatogenesis Mencit (Mus musculus) The Influence of Kebar Grass Infuse to Mice (Mus musculus) Spermatogenesis. 32(1), 55-67.

Mallick, C., Bera, T. K., Ali, K. M., Chatterjee, K., \& Ghosh, D. (2010). Diabetes-induced Testicular Disorders Vis-a-vis Germ Cell Apoptosis in Albino Rat: Remedial Effect of Hexane Fraction of Root of Musa paradisiaca and Leaf of Coccinia indica. Journal of Health Science, 56(6), 641-654. https://doi.org/10.1248/jhs.56.641

Maresch, C. C., Stute, D. C., Alves, M. G., Oliveira, P. F., de Kretser, D. M., \& Linn, T. (2018). Diabetes-induced hyperglycemia impairs male reproductive function: A systematic review. Human Reproduction Update, 24(1), 86-105. https://doi.org/10.1093/humupd/dmx033

Oladipo, G. O., Nlekerem, C. M., Ibukun, E. O., \& Kolawole, A. O. (2018). Quail (Coturnix japonica) egg yolk bioactive components attenuate streptozotocin-induced testicular damage and oxidative stress in diabetic rats. European Journal of Nutrition, 57(8), 28572867. https://doi.org/10.1007/s00394-017-1554-4

Öztaş, E., Yılmaz, T. E., Güzel, E., Sezer, Z., Okyar, A., \& Özhan, G. (2019). Gliclazide alone or in combination with atorvastatin ameliorated reproductive damage in streptozotocininduced type 2 diabetic male rats. Saudi Pharmaceutical Journal, 27(3), 422-431. https://doi.org/10.1016/j.jsps.2019.01.003

Rhee, S. Y., \& Kim, Y. S. (2018). The role of advanced glycation end products in diabetic vascular complications. Diabetes and Metabolism Journal, 42(3), 188-195. https://doi.org/10.4093/dmj.2017.0105

Sayuti, K., \& Rina, Y. (2015). Antioksidan Alami dan Sintetik. Padang: Andalas University Press.

Sembiring, B., \& Darwati, I. (2016). Identifikasi Komponen Kimia Aksesi Rumput Kebar (Biophytum petersianum) Asal Papua Dan Jawa. Buletin Penelitian Tanaman Rempab Dan Obat, 25(1), 37. https://doi.org/10.21082/bullittro.v25n1.2014.37-44

Singh, A., Milton, P., Nanaiah, A., Samuel, P., \& Thomas, N. (2012). Awareness and attitude toward diabetes in the rural population of Arunachal Pradesh, Northeast India. Indian Journal of Endocrinology and Metabolism, 16(7), 83. https://doi.org/10.4103/2230-8210.94269 
Tiwari, B. K., Pandey, K. B., Abidi, A. B., \& Rizvi, S. I. (2013). Markers of Oxidative Stress during Diabetes Mellitus. Journal of Biomarkers, 2013. https://doi.org/10.1155/2013/378790

Unitly, A. J. A., \& Inara, C. (2011). Biophytum petersianum. Prosiding Pengembangan Pulau-Pulau Kecil, 1(Sadsoeitoeboen), 329-333.

Xu, Y., Lei, H., Guan, R., Gao, Z., Li, H., Wang, L., Song, W., Gao, B., \& Xin, Z. (2014). Studies on the mechanism of testicular dysfunction in the early stage of a streptozotocin induced diabetic rat model. Biochemical and Biophysical Research Communications, 450(1), 87-92. https://doi.org/10.1016/j.bbrc.2014.05.067

Yue, D., Yan, L., Luo, H., Xu, X., \& Jin, X. (2010). Effect of Vitamin E supplementation on semen quality and the testicular cell membranal and mitochondrial antioxidant abilities in Aohan fine-wool sheep. Animal Reproduction Science, 118(2-4), 217-222. https://doi.org/10.1016/j.anireprosci.2009.08.004

Yuslianti, E.R. (2018). Pengantar Radikal Bebas dan Antioksidan. Yogyakarta: Deepublish. 